\title{
Premature cyclosporine cessation and TBI-containing conditioning regimen increase the risk of acute GvHD in children undergoing unrelated donor hematopoietic stem cell transplantation
}

\author{
Zofia Szmit ${ }^{A-F}$, Krzyszztof Kałwak ${ }^{A, C-F}$, Anna Krób, ${ }^{B, F}$, Monika Mielcarek-Siedziuk ${ }^{B, C, F}$, Małgorzata Salamonowicz ${ }^{B, C, F}$, \\ Jowita Frączkiewicz ${ }^{B, C, F}$, Marek Ussowicz ${ }^{B, E, F}$, Joanna Owoc-Lempach ${ }^{B, C, F}$ Ewa Gorczyńska ${ }^{A, C-F}$
}

Department and Clinic of Pediatric Hematology, Oncology and Bone Marrow Transplantation, Wroclaw Medical University, Supraregional Center of Pediatric Oncology

"Cape of Hope"

A - research concept and design; $B$ - collection and/or assembly of data; $C$ - data analysis and interpretation;

$D$ - writing the article; $E$ - critical revision of the article; $F$ - final approval of the article

Address for correspondence

Zofia Szmit

E-mail:zofia.lutrowicz@gmail.com

Funding sources

None declared

Conflict of interest

None declared

Received on November 4, 2018

Reviewed on November 13, 2018

Accepted on January 21, 2019

Published online on August 20, 2019

Cite as

Szmit Z, Kałwak K, Król A, et al. Premature cyclosporine cessation and TBI-containing conditioning regimen increase the risk of acute GvHD in children undergoing unrelated donor hematopoietic stem cell transplantation. Adv Clin Exp Med. 2019;28(9):1185-1192. doi:10.17219/acem/103069

D0I

10.17219/acem/103069

Copyright

Copyright by Author(s)

This is an article distributed under the terms of the

Creative Commons Attribution Non-Commercial License

(http://creativecommons.org/licenses/by-nc-nd/4.0/)

\section{Abstract}

Background. Acute graft-versus-host disease (aGvHD) is a potentially fatal complication after allogeneic hematopoietic stem cell transplantation (allo-HSCT). Identifying its risk factors would enable the proper prophylaxis and management, which may significantly improve the general outcome of children treated with HSCT.

Objectives. The aim of this single-center, retrospective cohort study was to assess the potential risk factors for grades III-IV of aGvHD in children after the $1^{\text {st }}$ allo-HSCT from an unrelated donor (UD), performed as a result of an underlying malignant disease.

Material and methods. From among patients who received HSCT in our center in the years 2004-2015, 237 were included in the study cohort. All the patients received standard aGvHD prophylaxis consisting of cyclosporine (CSA) and a short course of methotrexate (MTX). Various clinical and epidemiological features, the transplant proceedings, graft composition, conditioning regimens, as well as the duration and coherence of aGvHD prophylaxis were analyzed as potential risk factors for aGVHD.

Results. The incidence of II-IV aGvHD in the study cohort was 58.6\%. The median time of the diagnosis of aGVHD was 18 days post-HSCT. In the multivariate analysis, risk factors significantly associated with grades II-IV of aGvHD were: myeloablative conditioning regimen containing total body irradiation (TBI-MAC) (RR (relative risk): 1.69; $p=0.03$ ), premature termination of CSA administration due to its toxicity (RR: 1.99; $p=0.0003$ ) and HSCT performed before the year 2009 (RR: 1.97; $p=0.0001$ ). Donor and recipient age, donor-recipient sex mismatch, stem cell source, risk of disease, and amount of infused CD34+ cells seem to be insignificant as risk factors for aGvHD. The overall survival (OS) of patients with aGvHD was noticeably worse that in those who were aGVHD-free: $60.8 \%$ vs $74.1 \%(p=0.08)$.

Conclusions. The conditioning regimen and the proper aGvHD prophylaxis, including continuous CSA administration, have a major impact on aGVHD occurrence. According to our results, the termination of CSA therapy should be carefully considered, and avoided if possible.

Key words: risk factors, acute graft-versus-host disease, hematopoietic stem cell transplantation, prophylaxis 


\section{Introduction}

Acute graft-versus-host disease (aGvHD) remains one of the most common life-threatening complications after allogeneic hematopoietic stem cells transplantation (allo-HSCT), contributing significantly to morbidity and mortality. ${ }^{1}$ Several studies have reported numerous risk factors associated with increased incidence of aGvHD in the adult population. Among them, human leukocyte antigen (HLA) mismatch, type of the conditioning regimen, female donor to male recipient, and higher recipient age have proven to be the most valid. ${ }^{2-6}$ However, it needs to be highlighted that pediatric HSCTs differ remarkably from those in the adult population, particularly regarding the indications for transplant, existing comorbidities, previous treatment, and transplantation regimens.

In the pediatric population, the reported incidence of aGvHD varies from $30 \%$ to $80 \%$, despite given prophylaxis. ${ }^{2,7-10}$ First-line treatment for aGvHD is based mostly on high-dose steroids and turns out to be abortive in about $50 \%$ of cases. There are many possible second-line treatment agents and protocols, but, even when providing promising results, none of them have been proven unequivocally effective. ${ }^{11,12}$ On that account, not only is an intensive quest for successful second-line treatment for aGvHD needed, but first and foremost, a precise evaluation of its risk factors, especially for a pediatric cohort of patients.

The aim of this single-center, retrospective cohort study was to assess which potential risk factors have a significant influence on the frequency of grades II-IV of aGvHD in children with a malignant disease after the $1^{\text {st }}$ HSCT from an unrelated donor (UD). An analysis of the general outcome, overall survival (OS) and transplant-related mortality (TRM) in the studied cohort was the secondary aim of this research.

\section{Patients and methods}

A retrospective analysis of the medical records of the patients who underwent HSCT in the Department of Pediatric Hematology, Oncology and Bone Marrow Transplantation of Wroclaw Medical University (Poland) in the years 2004-2015 was performed. According to the inclusion criteria, all patients under 21 years who were suffering from a malignant disease and underwent the $1^{\text {st }}$ allo-HSCT procedure from an UD were considered in this study. Due to their small number, patients who received cord blood were excluded from the study. The final cohort included a total amount of 237 children and young adults (Table 1 ).

The grafted cells were obtained from human leukocyte antigen (HLA)-allele matched or mismatched UDs (age: 19-56 years; median age: 31 years). The HLA typing was performed at the high-resolution level (4 digits) in $\mathrm{A}^{*}, \mathrm{~B}$,
Table 1. Study cohort characteristics and analyzed risk factors for aGvHD

\begin{tabular}{|c|c|c|}
\hline Patients' characteristics & $\mathrm{n}$ & $\%$ \\
\hline $\begin{array}{l}\text { Diagnosis } \\
\text { acute leukemia } \\
\text { chronic myeloblastic leukemia } \\
\text { myelodysplastic syndrome } \\
\text { lymphoma }\end{array}$ & $\begin{array}{l}162 \\
28 \\
32 \\
15\end{array}$ & $\begin{array}{r}68.4 \\
11.8 \\
13.5 \\
6.3\end{array}$ \\
\hline $\begin{array}{l}\text { Patient sex } \\
\text { male } \\
\text { female }\end{array}$ & $\begin{array}{c}148 \\
89\end{array}$ & $\begin{array}{c}6.3 \\
37.6\end{array}$ \\
\hline $\begin{array}{l}\text { Donor-recipient sex mismatch } \\
\text { matched } \\
\text { male to female } \\
\text { female to male }\end{array}$ & $\begin{array}{l}142 \\
44 \\
51\end{array}$ & $\begin{array}{l}59.9 \\
18.6 \\
21.5\end{array}$ \\
\hline $\begin{array}{l}\text { Patient age [years] } \\
\leq 5 \\
>5 \text { and } \leq 15 \\
>15\end{array}$ & $\begin{array}{c}53 \\
129 \\
55\end{array}$ & $\begin{array}{l}22.4 \\
54.4 \\
23.2\end{array}$ \\
\hline $\begin{array}{l}\text { Donor age [years] (median: 31) } \\
\text { smedian } \\
\text { >median }\end{array}$ & $\begin{array}{l}123 \\
114\end{array}$ & $\begin{array}{l}51.9 \\
48.1\end{array}$ \\
\hline $\begin{array}{l}\text { Amount of CD34+ cells (median: } 8.29 \times 10^{6} / \mathrm{kg} \text { ) } \\
\leq \text { median } \\
>\text { median }\end{array}$ & $\begin{array}{l}119 \\
118\end{array}$ & $\begin{array}{l}50.2 \\
49.8\end{array}$ \\
\hline $\begin{array}{l}\text { Amount of CD34+ cellls (quartile - cut-off value) } \\
\text { Q1 }\left(5.01 \times 10^{6} / \mathrm{kg}\right) \\
\text { Q2 }\left(8.29 \times 10^{6} / \mathrm{kg}\right) \\
\text { Q3 }\left(12.09 \times 10^{6} / \mathrm{kg}\right) \\
\text { Q4 }\left(51.85 \times 10^{6} / \mathrm{kg}\right)\end{array}$ & $\begin{array}{l}60 \\
59 \\
60 \\
58\end{array}$ & $\begin{array}{l}25.3 \\
24.9 \\
25.3 \\
24.5\end{array}$ \\
\hline $\begin{array}{l}\text { Stem cells source } \\
\text { peripheral blood } \\
\text { bone marrow }\end{array}$ & $\begin{array}{c}201 \\
36\end{array}$ & $\begin{array}{l}84.8 \\
15.2\end{array}$ \\
\hline $\begin{array}{l}\text { Conditioning regimen } \\
\text { TBI-MAC } \\
\text { Bu-MAC } \\
\text { other (RTC/RIC) }\end{array}$ & $\begin{array}{c}84 \\
105 \\
48\end{array}$ & $\begin{array}{l}35.4 \\
44.3 \\
20.3\end{array}$ \\
\hline $\begin{array}{l}\text { Premature cessation of CsA } \\
\text { yes } \\
\text { no }\end{array}$ & $\begin{array}{c}47 \\
190\end{array}$ & $\begin{array}{l}19.8 \\
80.2\end{array}$ \\
\hline $\begin{array}{l}\text { Risk of disease } \\
\text { high } \\
\text { standard }\end{array}$ & $\begin{array}{l}115 \\
122\end{array}$ & $\begin{array}{l}48.5 \\
51.5\end{array}$ \\
\hline $\begin{array}{l}\text { Year of transplantation (median: 2009) } \\
\leq 2009 \\
>2009\end{array}$ & $\begin{array}{l}126 \\
111\end{array}$ & $\begin{array}{l}53.2 \\
46.8\end{array}$ \\
\hline $\begin{array}{l}\text { Year of transplantation (quartile) } \\
\text { Q1 (2004-2006) } \\
\text { Q2 (2007-2009) } \\
\text { Q3 (2010-2012) } \\
\text { Q4 (2013-2015) }\end{array}$ & $\begin{array}{l}72 \\
54 \\
58 \\
53\end{array}$ & $\begin{array}{l}30.4 \\
22.8 \\
24.5 \\
22.3\end{array}$ \\
\hline
\end{tabular}

TBI-MAC - myeloablative conditioning regimen containing total body irradiation; Bu-MAC - myeloablative conditioning regimen containing busulfan; RTC - reduced-toxicity conditioning; RIC - reduced-intensity conditioning; CsA - cyclosporine.

$\mathrm{CW}^{*}, \mathrm{DRB1}$, and DQB1* alleles. A matched donor was defined as 10/10 or 9/10 HLA-compatible donor. More than 1 mismatched allele was defined as a mismatched unrelated donor (MMUD). According to the ALL-SCT BFM International 2008 criteria, all 10 alleles were highresolution types. 


\section{Graft-versus-host disease prophylaxis}

Within the standard prophylaxis for aGvHD, all patients, since the day before HSCT received intravenous cyclosporine (CsA) in a unified initial dose of $1.5 \mathrm{mg} / \mathrm{kg}$ twice per day in 2-hour infusions. Further dosage of CsA was adjusted to the CsA trough level (target level: 100-200 $\mu \mathrm{g} / \mathrm{L}$ ), measured every second day in the majority of patients. Therefore, the dosage was modified to maintain the target level. Cyclosporine was switched into oral formulation when patient was able to tolerate oral intake. According to standard protocols, in patients without signs of GvHD, CsA administration was discontinued on day 120 in the majority of cases, preceded by gradual dose reduction. The $2^{\text {nd }}$ prophylactic agent, methotrexate (MTX), was administered threefold in a standard dose of $10 \mathrm{mg} / \mathrm{m}^{2}$ on days 1,3 and 6 after HSCT. All patients were given in vivo T-cell depletion by either rabbit anti-thymocyte globulin (ATG) $(\mathrm{n}=229)$ (ATG-Fresenius/Grafalon ${ }^{\circledR}$ (Neovii Biotech GmbH, Gräfelfing, Germany) - median: $45 \mathrm{mg} / \mathrm{kg}$; or Thymoglobuline ${ }^{\circledR}$ (Genzyme Europe B.V., Naarden, the Netherlands) - median $7.5 \mathrm{mg} / \mathrm{kg}$ ) or Campath-1H (Genzyme Europe BV) ( $\mathrm{n}=8)$ (median: $1 \mathrm{mg} / \mathrm{kg}$ ).

\section{Acute graft-versus-host disease diagnosis and staging}

The diagnosis of aGvHD was based on the clinical findings and/or histopatological findings in the skin, gastrointestinal tract mucosa and liver biopsies. ${ }^{13-15}$ Grading and staging of aGvHD was performed using pediatricspecific criteria published by Jacobsohn. ${ }^{15}$ In the presented research, only grades II-IV were considered. Patients who presented symptoms of aGvHD after donor lymphocyte infusion were excluded from this study.

\section{Risk factors and definitions}

Potential risk factors for developing aGvHD were carefully analyzed and are listed in Table 2 . The patients' risk status was defined by our own study-specific modification of the classification proposed by Meisel et al. ${ }^{16}$ Acute leukemia (AL) in $1^{\text {st }}$ complete remission (1CR), chronic myeloblastic leukemia (CML) in chronic phase (CP), myelodysplastic syndrome-refractory cytopenia (MDS), and non-Hodgkin lymphoma (NHL) in complete remission (CR) was qualified as a standard risk. Acute leukemia in $\geq 2 \mathrm{CR}$ or non-remission, $\mathrm{CML}$ in equal to or greater than accelerating phase, MDS-refractory anemia with an excess of blasts, NHL in non-remission, and juvenile myelomonocytic leukemia (JMML) were defined as a high risk. Early termination of CsA administration was defined as termination before day 60 post-HSCT due to the toxicity of CsA. Cyclosporine-induced nephrotoxicity was diagnosed according to the following criteria: fall in baseline glomerular filtration rate - GFR $>25 \%$ or doubling the serum creatinine level. ${ }^{17}$ Neurotoxicity was defined as seizures, polyneuropathy, ataxy, impaired consciousness, or dizziness. ${ }^{18}$ Children with other obvious causes of neuro- and nephrotoxicity were excluded. Only patients who presented first symptoms of aGvHD after the cessation of CsA administration were considered under the influence of this risk factor.

\section{Conditioning regimens}

As many as 189 patients received myeloablative conditioning regimen (MAC) based either on myeloablative doses (12.8-19.6 mg/kg) of busulfan (Bu-MAC; $\mathrm{n}=105)$, or on total body irradiation (TBI) at a median dose of $12 \mathrm{~Gy}$ (TBI-MAC; $\mathrm{n}=84$ ). Thirty-eight patients received reduced-toxicity conditioning (RTC), consisting mainly of fludarabine $\left(160 \mathrm{mg} / \mathrm{m}^{2}\right)$ and treosulfan $(36-42 \mathrm{mg} / \mathrm{kg})$ with thiotepa $(10 \mathrm{mg} / \mathrm{kg})$, melphalan $\left(140 \mathrm{mg} / \mathrm{m}^{2}\right)$ or cyclophosphamide $(120 \mathrm{mg} / \mathrm{kg})$. Ten patients received reducedintensity conditioning (RIC) regimen, consisting of fludarabine with either melphalan or low, non-myeloablative doses of busulfan $(2 \mathrm{mg} / \mathrm{kg}){ }^{19,20}$ In the statistical analysis, patients receiving RIC and RTC were considered collectively as 1 group.

\section{Statistical analysis}

The statistical analysis was performed using $\mathrm{R}$ statistical software (https://www.r-project.org/). Variables were analyzed in terms of their prognostic impact on aGvHD, OS and TRM. First, powered by the $\chi^{2}$ test, we compared the baseline characteristics of patients with II-IV aGvHD and those with either no aGvHD or grade I aGvHD. Thereafter, patient data was entered into a competing risk regression model. We prosecuted 5 variants of regression models, containing either all or only the significant factors. Using the Bayesian Information Criterion (BIC) test, we selected the most adequate model. Acute graft-versushost disease was defined by the abovementioned criteria, analyzed as time to event with death, relapse or rejection without aGvHD as a competing event. The p-values $<0.05$ were considered significant. The survival analysis was performed using the Kaplan-Meier estimation and the survival graphs were compared using the log-rank test. Since aGvHD is a time-dependent variable, we applied the landmark analysis at day 100 to the poor-prognosis group in order to avoid bias connected with autoselection. All patients who died or did not undergo a follow-up before day 100 were deleted from the survival analysis.

\section{Results}

A total of 237 patients underwent the $1^{\text {st }}$ allo-HSCT from an UD. Two hundred thirty patients received stem cells from matched donor and 7 patients received stem cells 
from MMUD (8/10). One hundred thirty-nine patients (58.6\%) developed aGvHD stage II-IV within 100 days post-HSCT. The time of aGvHD diagnosis varied from 5 days post-HSCT up to 92 days post-HSCT (median: 18 days). Seventy-eight patients (32.9\%) did not develop aGvHD or developed only stage I with no need for systemic treatment. Twenty (8.5\%) of those who did not develop aGvHD encountered a competing event, such as graft rejection, relapse or death before day 100 .

Forty-seven patients (19.8\%) presented CsA-associated toxicity and required cessation of the therapy. The most common CsA toxicity observed in the study population was nephrotoxicity $(\mathrm{n}=22)$ and neurotoxicity $(\mathrm{n}=19)$.
Six patients presented other, more unspecific symptoms, such as allergic reactions $(n=5)$ and microangiopathy $(\mathrm{n}=1)$. The beginning of CsA treatment discontinuation varied from 1 day post-HSCT up to 52 days post-HSCT (median: 15 days). Instead of CsA, the majority of patients $(\mathrm{n}=45$; 96\%) received Mycofenolate Mofetil (MMF) intravenously at a standard prophylactic dose $(20 \mathrm{mg} / \mathrm{kg} /$ day). Four of those patients received additional steroids at a standard dose of $1 \mathrm{mg} / \mathrm{kg} /$ day. Two (4\%) patients received steroids alone.

Initially, we performed the univariate statistical analysis. In this analysis, 3 factors significantly increased the probability of aGvHD ( $<0.05)$ : TBI-MAC ( $\mathrm{p}=0.0272)$,

Table 2. Univariate analysis of risk factors for acute graft-versus-host disease (aGvHD)

\begin{tabular}{|c|c|c|c|c|}
\hline \multirow[b]{2}{*}{ Risk factors } & \multicolumn{3}{|c|}{ aGvHD } & \multirow[b]{2}{*}{$p$-value } \\
\hline & $\begin{array}{l}\text { yes } \\
\mathrm{n}[\%]\end{array}$ & $\begin{array}{l}\text { no (without a competing event) } \\
\text { n [\%] }\end{array}$ & $\begin{array}{l}\text { no (with a competing event) } \\
\mathrm{n}[\%]\end{array}$ & \\
\hline $\begin{array}{l}\text { Patient sex } \\
\text { male } \\
\text { female }\end{array}$ & $\begin{array}{l}87(62.6) \\
52(37.4)\end{array}$ & $\begin{array}{l}53(67.9) \\
25(32.1)\end{array}$ & $\begin{array}{l}8(40) \\
12(60)\end{array}$ & 0.0705 \\
\hline $\begin{array}{l}\text { Sex mismatch } \\
\text { matched } \\
\text { male to female } \\
\text { female to male }\end{array}$ & $\begin{array}{l}85(61.2) \\
27(19.4) \\
27(19.4)\end{array}$ & $\begin{array}{l}48(61.6) \\
15(19.2) \\
15(19.2)\end{array}$ & $\begin{array}{l}9(45) \\
2(10) \\
9(45)\end{array}$ & 0.1221 \\
\hline $\begin{array}{l}\text { Patient age [years] } \\
\leq 5 \\
>5 \text { and }<15 \\
\geq 15\end{array}$ & $\begin{array}{l}33(23.7) \\
76(54.7) \\
30(21.6)\end{array}$ & $\begin{array}{l}13(16.7) \\
45(57.7) \\
20(25.6)\end{array}$ & $\begin{array}{l}7(35) \\
8(40) \\
5(25)\end{array}$ & 0.4084 \\
\hline $\begin{array}{l}\text { Donor age [years] (median: 31) } \\
\text { smedian } \\
\text { >median }\end{array}$ & $\begin{array}{l}74(53.2) \\
65(46.8)\end{array}$ & $\begin{array}{l}41(52.6) \\
37(47.4)\end{array}$ & $\begin{array}{l}8(40) \\
12(60)\end{array}$ & 0.5358 \\
\hline $\begin{array}{l}\text { Amount of CD34+ cells (median: } 8.29 \times 10^{6} / \mathrm{kg} \text { ) } \\
\leq \text { median } \\
\text { >median }\end{array}$ & $\begin{array}{l}65(46.8) \\
74(53.2)\end{array}$ & $\begin{array}{l}42(53.8) \\
36(46.2)\end{array}$ & $\begin{array}{l}12(60) \\
8(40)\end{array}$ & 0.3985 \\
\hline $\begin{array}{l}\text { Amount of CD34+ cells (quartile - cut-off value) } \\
\text { Q1 }\left(5.01 \times 10^{6} / \mathrm{kg}\right) \\
\text { Q2 }\left(8.29 \times 10^{6} / \mathrm{kg}\right) \\
\text { Q3 }\left(12.09 \times 10^{6} / \mathrm{kg}\right) \\
\text { Q4 }\left(51.85 \times 10^{6} / \mathrm{kg}\right)\end{array}$ & $\begin{array}{l}32(23) \\
33(23.7) \\
35(25.2) \\
39(28.1)\end{array}$ & $\begin{array}{l}22(28.2) \\
20(25.6) \\
21(26.9) \\
15(19.3)\end{array}$ & $\begin{array}{l}6(30) \\
6(30) \\
4(20) \\
4(20)\end{array}$ & 0.7970 \\
\hline $\begin{array}{l}\text { Stem cells source } \\
\text { peripheral blood } \\
\text { bone marrow }\end{array}$ & $\begin{array}{l}115(82.7) \\
24(17.3)\end{array}$ & $\begin{array}{l}68(87.2) \\
10(12.8)\end{array}$ & $\begin{array}{l}18(90) \\
2(10)\end{array}$ & 0.5425 \\
\hline $\begin{array}{l}\text { Conditioning regimen } \\
\text { TBI-MAC } \\
\text { Bu-MAC } \\
\text { other (RTC/RIC) }\end{array}$ & $\begin{array}{l}59(42.4) \\
59(42.4) \\
21(15.2)\end{array}$ & $\begin{array}{l}39(50) \\
19(24.4) \\
20(25.6)\end{array}$ & $\begin{array}{l}7(35) \\
6(30) \\
7(35)\end{array}$ & 0.0272 \\
\hline $\begin{array}{l}\text { Premature discontinuation of CsA } \\
\text { yes } \\
\text { no }\end{array}$ & $\begin{array}{l}36(25.9) \\
103(74.1)\end{array}$ & $\begin{array}{c}7(9) \\
71(91)\end{array}$ & $\begin{array}{c}2(10) \\
18(90)\end{array}$ & 0.0201 \\
\hline $\begin{array}{l}\text { Risk of disease } \\
\text { high } \\
\text { standard }\end{array}$ & $\begin{array}{l}71(51.1) \\
68(48.9)\end{array}$ & $\begin{array}{l}36(46.2) \\
42(53.8)\end{array}$ & $\begin{array}{c}8(40) \\
12(60)\end{array}$ & 0.5711 \\
\hline $\begin{array}{l}\text { Year of transplantation (median: 2009) } \\
\leq 2009 \\
>2009\end{array}$ & $\begin{array}{l}88(63.3) \\
51(36.7)\end{array}$ & $\begin{array}{l}33(42.3) \\
45(57.7)\end{array}$ & $\begin{array}{c}5(25) \\
15(75)\end{array}$ & 0.0004 \\
\hline $\begin{array}{l}\text { Year of transplantation (quartile) } \\
\text { Q1 (2004-2006) } \\
\text { Q2 (2007-2009) } \\
\text { Q3 (2010-2012) } \\
\text { Q4 (2013-2015) }\end{array}$ & $\begin{array}{l}54(38.8) \\
34(24.5) \\
32(23) \\
19(13.7)\end{array}$ & $\begin{array}{l}17(21.8) \\
16(20.5) \\
17(21.8) \\
28(35.9)\end{array}$ & $\begin{array}{c}1(5) \\
4(20) \\
9(45) \\
6(30)\end{array}$ & 0.0003 \\
\hline
\end{tabular}


preemptive discontinuation of CsA ( $\mathrm{p}=0.0201)$ and transplantation performed before year 2009 ( $p=0.0004)$. Donor and recipient age, patient sex, donor-recipient sex mismatch, amount of infused CD34+ cells, stem cell source, and underlying disease stage seemed to be insignificant as risk factors for aGvHD (Table 2).

The same factors as in the univariate analysis proved to be significant in the multivariate analysis. The myeloablative conditioning regimen containing total body irradiation puts patients in a greater risk of aGvHD (RR (relative risk): $1.69 ; 95 \%$ confidence interval $(95 \% \mathrm{CI})=1.047-2.74$; $\mathrm{p}=0.0320)$. Premature discontinuation of CsA significantly increased the risk of aGvHD $(\mathrm{RR}=1.99 ; 95 \% \mathrm{CI}=1.369-2.89$; $\mathrm{p}=0.0003)$. Transplantation performed before 2009 enhanced the possibility of aGvHD ( $\mathrm{RR}=1.97$; $95 \% \mathrm{CI}=1.400-2.78$; $\mathrm{p}=0.0001)$. The relative risk regression model containing all significant factors is presented in Table 3.

Table 3. Results of multivariate analysis, competing risk regression model

\begin{tabular}{|l|c|c|}
\multicolumn{1}{|c|}{ Risk factors } & RR $(95 \% \mathrm{Cl})$ & $\mathrm{p}$-value \\
\hline $\begin{array}{l}\text { Conditioning regimen } \\
\text { other (RTC/RIC) }\end{array}$ & 1 & - \\
Bu-MAC & $1.11(0.673-1.85)$ & 0.67 \\
TBI-MAC & $1.69(1.047-2.74)$ & 0.0320 \\
\hline $\begin{array}{l}\text { Early cessation of CsA } \\
\text { no }\end{array}$ & 1 & - \\
yes & $1.99(1.369-2.89)$ & 0.0003 \\
\hline $\begin{array}{l}\text { Year of transplantation (median: 2009) } \\
\text { >median } \\
\text { smedian }\end{array}$ & 1 & - \\
\hline
\end{tabular}

$\mathrm{RR}$ - relative risk; $\mathrm{Cl}$ - confidence interval.

The median follow-up in the study cohort, which was 2.3 years after HSCT, revealed that 138 patients remained alive. The general outcome in the aGvHD cohort was noticeably worse (TRM $=22.5 \%$; OS $=60.8 \%$ ) compared to aGvHD-free patients (TRM = 12\%; OS = 74.1\%). The difference between OS $(\mathrm{p}=0.08)$ and TRM in both groups was at the limit of statistical significance $(\mathrm{p}=0.08)$. Transplantation performed before 2009 contributed significantly to a worse survival $(\mathrm{p}=0.019)$ and increased TRM ( $\mathrm{p}=0.049$ ) (Fig. 1,2). Other factors, including those which statistically impact the incidence of aGvHD, did not influence OS and TRM (data not shown). Complete OS and TRM statistics are presented in Table 4.

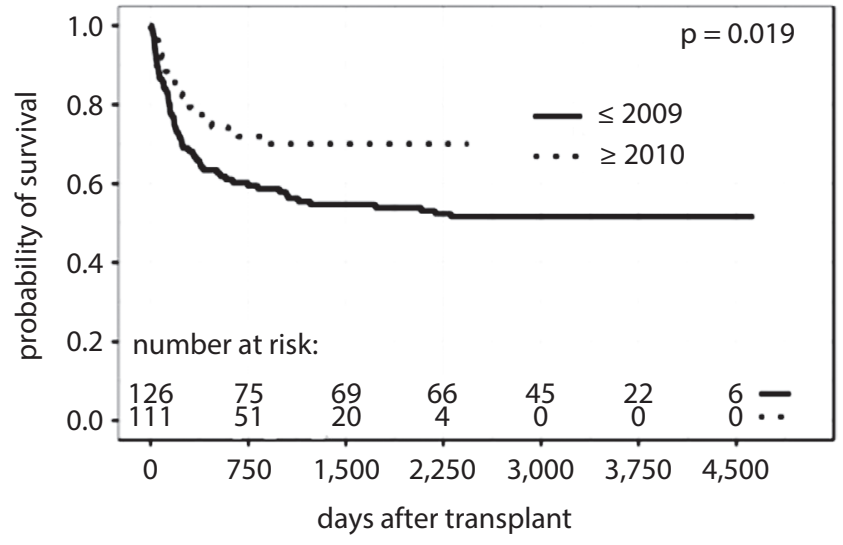

Fig. 1. Comparison of overall survival (OS) for patients receiving hematopoietic stem cell transplantation (HSCT) before and after 2009

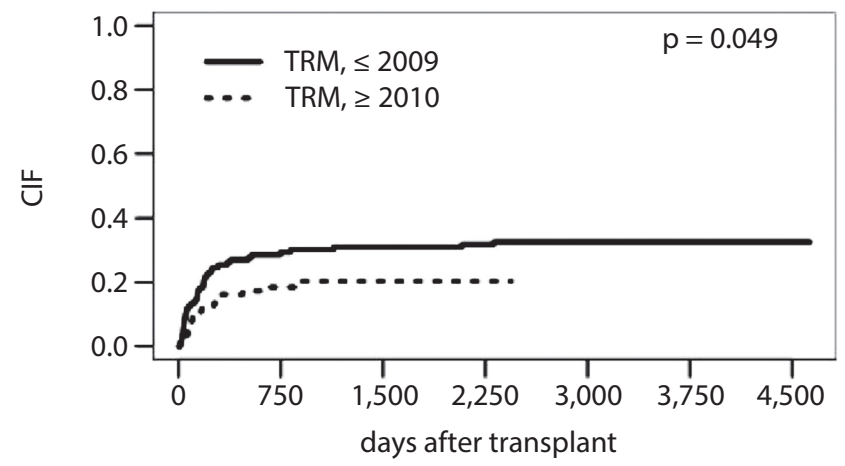

Fig. 2. Comparison of transplant-related mortality (TRM) for patients receiving hematopoietic stem cell transplantation (HSCT) before and after 2009

CIF - cumulative incidence function.

\section{Discussion}

Acute graft-versus-host disease as a major factor affecting morbidity and mortality in the early period post-HSCT still remains a challenge for clinicians and researchers worldwide. There is a great number of published studies attributing both the incidence of aGvHD and the general outcome to the influence of potential risk factors. Repeatedly, those studies demonstrate different or even contradictory results. However, it should be emphasized that most of the studies were performed on adult patients and lack of great cohort research conducted on the pediatric population is unquestionable.

Table 4. Comparison of overall survival (OS) and transplant-related mortality (TRM) in patients with or without acute graft-versus-host disease (aGvHD)

\begin{tabular}{|c|c|c|c|c|c|c|}
\hline \multirow{2}{*}{ Time post HSCT } & \multicolumn{2}{|c|}{ OS [\%] } & \multirow{2}{*}{$p$-value } & \multicolumn{2}{|c|}{ TRM [\%] } & \multirow{2}{*}{$p$-value } \\
\hline & aGvHD & no aGvHD & & aGvHD & no aGvHD & \\
\hline 1 year & 87.0 & 90.3 & & 13.8 & 8.7 & \\
\hline 3 years & 72.2 & 85.3 & & 18.6 & 12.2 & \\
\hline 5 years & 60.4 & 74.1 & 0.084 & 25.9 & 12.8 & 0.145 \\
\hline
\end{tabular}


The incidence of aGvHD in our study (58.6\%) is very similar to that presented in other studies, but there are also some reports referring to a much higher frequency of this complication, reaching the level of $80 \%{ }^{1,2,9,10,23,24}$ Such discrepancies may be due to meaningful differences in the studied cohorts. In our study, patient selection was defined by strict criteria; therefore, the analyzed cohort was relatively homogenous.

A comparison of conditioning regimens Bu-MAC vs TBIMAC vs other (RTC \& RIC) shows TBI as a major risk factor for aGvHD in the pediatric population. ${ }^{21,22}$ Tissue damage, particularly in the gastrointestinal tract, undoubtedly exacerbated by TBI, is thought to be the $1^{\text {st }}$ stage of inflammatory reaction through the activation of host antigenpresenting cells (APCs) and cytokine production. This may initiate an inflammatory cascade, leading to the development of aGvHD. ${ }^{28}$ Lack of significant differences between the $\mathrm{Bu}-\mathrm{MAC}$ patients and the group receiving $\mathrm{RTC}$ and RIC may suggest that chemo-based myeloablative regimens would not influence aGvHD development. ${ }^{29,30}$ This finding only highlights the contribution of TBI to aGvHD. There are also some studies suggesting that in younger recipients, a low dose of TBI may have a beneficial effect without increasing the risk for aGvHD. This indicates that reduced-toxicity regimens, containing low doses of TBI, could be further investigated also in pediatric HSCT recipients. However, in our study, the best survival rate was noted in the group of patients with Bu-MAC (data not shown). This finding may suggest that chemo-based MAC could be a golden standard for pediatric patients. ${ }^{31}$

Premature discontinuation of CsA increased the probability of aGvHD. There are a lot of reports in the literature about the essential role of calcineurin inhibitors in aGvHD prophylaxis. A large part of these reports focus on the superiority of one of them (CsA or tacrolimus) over the other. Another great part of the literature proves that a low plasma concentration level of CsA, especially in the early period post-HSCT (i.e., 2-3 weeks post-HSCT) is associated with a much higher risk of aGvHD. ${ }^{26,32-35}$ To our knowledge, this is the only study providing results that refer to the influence of early cessation of CsA on the occurrence of aGvHD. There is only one reference regarding premature discontinuation of CsA - the research conducted by Cadenas et al. ${ }^{32}$ Although this study was performed on a completely different population of patients, it contains a brief suggestion that there is no connection between discontinuation of CsA and aGvHD. The quoted study primarily focused on low CsA plasma concentration levels as a risk factor for aGvHD. To date, the optimal therapeutic approach for CsA therapy as aGvHD prophylaxis after HSCT remains unclear in terms of doses as well as the monitoring strategy. ${ }^{36,37}$ However, our results indicate that calcineurin inhibitors as part of aGvHD prophylaxis may be irreplaceable.

Hematopoietic stem cells transplantation performed before 2009 proved to be a crucial risk factor for the development of aGvHD and contributed to a worse general outcome. This finding is a reflection of all the improvements in donor selection, transplantation regimens and supportive care that were made during the analyzed period of time. Furthermore, improved OS and reduced TRM after 2009 result from relevant advances in aGvHD therapy that were made during these years. Among all implemented GvHD treatment strategies, extracorporeal photopheresis seems to be promising both in our center (data not shown) and worldwide.

The CD34+ cell dose is one of the most ambiguous factors that have an impact on aGvHD and survival after HSCT. The results of our study showed no correlation between a greater amount of transplanted CD34+ cells and a higher incidence of aGvHD. In parallel, we found no interdependence between the CD34+ cells dose and either OS or TRM. Several studies, performed in both the adult and pediatric population of patients, confirm our findings. Previous research conducted in our center by Kałwak et al. also proves that there is no correlation between the CD34+ cell dose and aGvHD; notwithstanding, a greater amount of transplanted CD34+ cells contributed to better OS and general outcome. ${ }^{9}$ Similar results were reported by Pulsipher at al. in a multi-center study performed on a great cohort of adult and pediatric patients. ${ }^{38}$ Another study demonstrating no correlation between CD34+ and aGvHD was carried out by Tsirigotis et al. ${ }^{39}$ It also reports that the number of infused CD34+ cells has no influence on the general outcome. On the contrary, there are some reports suggesting that a higher number of infused CD34 cells may be a risk factor for aGvHD. ${ }^{5,40}$ The extremely discrepant findings concerning the impact of the CD34+ cell dose on aGvHD show that this variable should be analyzed individually, following the patient requirements. This knowledge can be beneficial, allowing clinicians to tailor the composition of the graft in accordance with the patient status and other peri-transplantation variables.

Other analyzed variables, such as donor and recipient age as well as donor-recipient sex mismatch, are wellknown risk factors for aGvHD in the adult population. In children, however, the data is sparse. In our study, female donor to male recipient did not prove to be a risk factor for aGVHD, which was, however, noted as a risk factor in our population of male matched sibling donor recipients, when no ATG was given (data not shown).

\section{Conclusions}

To conclude, conditioning regimen and adequate immunosuppressive prophylaxis, including continuous CsA use, remain major factors affecting the incidence of aGvHD in children with malignant disorders undergoing UD-HSCT. However, to date, it is not possible to provide strict guidelines for minimizing the risk of aGvHD. According to our results, 
the decision to stop CsA administration should be carefully considered, and avoided if possible. Choosing an approach may be discussed if CsA needs to be discontinued for some reason. There is no clear answer. Both MMF and steroids could be useful, but in our belief, MMF seems to be the most appropriate option, with less toxicity.

\section{ORCID iDs}

Zofia Szmit (10 https://orcid.org/0000-0002-1069-9404

Krzysztof Kałwak (1) https://orcid.org/0000-0003-1174-5799

Monika Mielcarek-Siedziuk (1) https://orcid.org/0000-0003-2745-120X

Małgorzata Salamonowicz (1) https://orcid.org/0000-0003-1736-3177

Marek Ussowicz (i) https://orcid.org/0000-0001-5725-4835

Joanna Owoc-Lempach (1) https://orcid.org/0000-0001-7329-4079

Ewa Gorczyńska (1) https://orcid.org/0000-0002-5709-6731

Anna Król (10) https://orcid.org/0000-0001-5791-4215

Jowita Frączkiewicz (10) https://orcid.org/0000-0002-8467-8788

\section{References}

1. Faraci M, Caviglia I, Biral E, et al. Acute graft-versus-host disease in pediatric allogeneic hematopoietic stem cell transplantation. Singlecenter experience during 10 yr. Pediatr Transplant. 2012;16(8):887-893 . doi:10.1111/petr.12009

2. Flowers $\mathrm{ME}$, Inamoto $\mathrm{Y}$, Carpenter PA, et al. Comparative analysis of risk factors for acute graft-versus-host disease and for chronic graft-versus-host disease according to National Institutes of Health consensus criteria. Blood. 2011;117(11):3214-3219. doi:10.1182/blood2010-08-302109

3. Kollman C, Howe CW, Anasetti C, et al. Donor characteristics as risk factors in recipients after transplantation of bone marrow from unrelated donors: The effect of donor age. Blood. 2001;98(7):2043-2051. doi:10.1182/blood.V98.7.2043

4. Harris AC, Ferrara JLM, Levine JE. Advances in predicting acute GVHD. BrJ Haematol. 2013;160(3):288-302. doi:10.1111/bjh.12142

5. Remberger M, Mattsson J, Hassan Z, et al. Risk factors for acute graftversus-host disease grades II-IV after reduced intensity conditioning allogeneic stem cell transplantation with unrelated donors: A single centre study. Bone Marrow Transplant. 2008;41(4):399-405. doi:10. 1038/sj.bmt.1705913

6. Lee SJ, Klein J, Haagenson M, et al. High-resolution donor-recipient HLA matching contributes to the success of unrelated donor marrow transplantation. Blood. 2007;110(13):4576-4583. doi:10.1182/blood2007-06-097386

7. Shaw PJ, Kan F, Woo Ahn K, et al. Outcomes of pediatric bone marrow transplantation for leukemia and myelodysplasia using matched sibling, mismatched related, or matched unrelated donors. Blood. 2010;116(19):4007-4015. doi:10.1182/blood-2010-01-261958

8. MacMillan ML, Weisdorf DJ, Brunstein CG, et al. Acute graft-versushost disease after unrelated donor umbilical cord blood transplantation: Analysis of risk factors. Blood. 2009;113(11):2410-2415. doi:10. 1182/blood-2008-07-163238

9. Kałwak K, Porwolik J, Mielcarek M, et al. Higher CD34(+) and CD3(+) cell doses in the graft promote long-term survival, and have no impact on the incidence of severe acute or chronic graft-versus-host disease after in vivo T cell-depleted unrelated donor hematopoietic stem cell transplantation in children. Biol Blood Marrow Transpl. 2010;16(10): 1388-1401. doi:10.1016/j.bbmt.2010.04.001

10. Carlens S, Aschan J, Remberger M, Dilber M, Ringdén O. Low-dose cyclosporine of short duration increases the risk of mild and moderate GVHD and reduces the risk of relapse in HLA-identical sibling marrow transplant recipients with leukaemia. Bone Marrow Transplant. 1999;24(6):629-635.

11. Ferrara JL, Levine JE, Reddy $\mathrm{P}$, Holler E. Graft-versus-host disease. Lancet. 2009;373(9674):1550-1561. doi:10.1016/S0140-6736(09)60237-3

12. Martin PJ, Rizzo JD, Wingard JR, et al. First- and second-line systemic treatment of acute graft-versus-host disease: Recommendations of the American Society of Blood and Marrow Transplantation. Biol Blood Marrow Transplant. 2012;18(8):1150-1163. doi:10.1016/j.bbmt. 2012.04.005
13. Glucksberg H, Storb R, Fefer A, et al. Clinical manifestations of graftversus-host disease in human recipients of marrow from HL-Amatched sibling donors. Transplantation. 1974;18(4):295-304.

14. Jagasia MH, Greinix HT, Arora M, et al. National Institutes of Health consensus development project on criteria for clinical trials in chronic graft-versus-host disease: I. The 2014 Diagnosis and Staging Working Group report. Biol Blood Marrow Transpl. 2015;21(3):389-401. doi:10. 1016/j.bbmt.2014.12.001

15. Jacobsohn DA. Acute graft-versus-host disease in children. Bone Marrow Transplant. 2008;41(2):215-221. doi:10.1038/sj.bmt.1705885

16. Meisel R, Laws HJ, Balzer S, et al. Comparable long-term survival after bone marrow versus peripheral blood progenitor cell transplantation from matched unrelated donors in children with hematologic malignancies. 2007;13(11):1338-1345. doi:10.1016/j.bbmt.2007.07.009

17. Bastoni da Silva J, de Melo Lima MH, Secoli SR. Influence of cyclosporine on the occurrence of nephrotoxicity after allogeneic hematopoietic stem cell transplantation: A systematic review. Rev Bras Hematol Hemoter. 2014;36(5):363-368. doi:10.1016/j.bjhh.2014.03.010

18. Noè A, Cappelli B, Biffi A, et al. High incidence of severe cyclosporine neurotoxicity in children affected by haemoglobinopaties undergoing myeloablative haematopoietic stem cell transplantation: Early diagnosis and prompt intervention ameliorates neurological outcome. Ital J Pediatr. 2010;36:14.

19. Bacigalupo A, Ballen K, Rizzo D, et al. Defining the intensity of conditioning regimens: Working definitions. Biol Blood Marrow Transplant. 2009;15(12):1628-1633. doi:10.1016/j.bbmt.2009.07.004

20. Slatter MA, Rao H, Amrolia P, et al. Treosulfan-based conditioning regimens for hematopoietic stem cell transplantation in children with primary immunodeficiency: United Kingdom experience. Blood. 2011;117(16):4367-4375. doi:10.1182/blood-2010-10-312082

21. Pulsipher MA, Boucher KM, Wall $D$, et al. Reduced-intensity allogeneic transplantation in pediatric patients ineligible for myeloablative therapy: Results of the Pediatric Blood and Marrow Transplant Consortium Study ONC0313. Blood. 2009;114(7):1429-1436. doi:10.1182/ blood-2009-01-196303

22. Wachowiak J, Sykora KW, Cornish J, et al. Treosulfan-based preparative regimens for allo-HSCT in childhood hematological malignancies: A retrospective study on behalf of the EBMT pediatric diseases working party. Bone Marrow Transplant. 2011;46(12):1510-1518. doi:10.1038/bmt.2010.343

23. Davies SM, Wang D, Wang T, et al. Recent decrease in acute graft-versus-host disease in children with leukemia receiving unrelated donor bone marrow transplants. Biol Blood Marrow Transplant. 2009;15(3): 360-366. doi:10.1016/j.bbmt.2008.12.495

24. Jagasia M, Arora M, Flowers ME, et al. Risk factors for acute GVHD and survival after hematopoietic cell transplantation. Blood. 2012;119(1): 296-307. doi:10.1182/blood-2011-06-364265

25. Pérez-Simón JA, Díez-Campelo M, Martino R. Influence of the intensity of the conditioning regimen on the characteristics of acute and chronic graft-versus-host disease after allogeneic transplantation. Br J Haematol. 2005;130(3):394-403. doi:10.1111/j.1365-2141. 2005.05614.x

26. Nash RA, Pepe MS, Storb R, et al. Acute graft-versus-host disease: Analysis of risk factors after allogeneic marrow transplantation and prophylaxis with cyclosporine and methotrexate. Blood. 1992;80(7): 1838-1845.

27. Lee $\mathrm{SE}, \mathrm{Cho} \mathrm{BS}$, Kim JH, et al. Risk and prognostic factors for acute GVHD based on NIH consensus criteria. Bone Marrow Transplant. 2013;48(4):587-592. doi:10.1038/bmt.2012.187

28. Washington K, Jagasia M. Pathology of graft-versus-host disease in the gastrointestinal tract. Hum Pathol. 2009;40(7):909-917. doi:10. 1016/j.humpath.2009.04.001

29. Nagler A, Rocha V, Labopin M, et al. Allogeneic hematopoietic stemcell transplantation for acute myeloid leukemia in remission: Comparison of intravenous busulfan plus cyclophosphamide (Cy) versus total-body irradiation plus Cy as conditioning regimen - a report from the acute leukemia working party of the European group for blood and marrow transplantation. J Clin Oncol. 2013;31(28):35493556. doi:10.1200/JCO.2013.48.8114

30. Nakasone H, Fukuda T, Kanda J, et al. Impact of conditioning intensity and TBI on acute GVHD after hematopoietic cell transplantation. Bone Marrow Transplant. 2015;50(4):559-565. doi:10.1038/bmt.2014.293 
31. Shi-Xia X, Hai-Qin X, Xian-Hua T, Bo F, Xiang-Feng T. Comparison of reduced intensity and myeloablative conditioning regimens for stem cell transplantation in patients with malignancies: A meta-analysis. Clin Transplant. 2011;25(2):E187-E198. doi:10.1111/j.1399-0012. 2010.01361

32. García Cadenas I, Valcarcel D, Martino R, et al. Impact of cyclosporine levels on the development of acute graft versus host disease after reduced intensity conditioning allogeneic stem cell transplantation. Mediators Inflamm. 2014;2014:620682. doi:10.1155/2014/620682

33. Willemze AJ, Press RR, Lankester AC, Egeler RM, den Hartigh J, Vossen JM. CsA exposure is associated with acute GVHD and relapse in children after SCT. Bone Marrow Transplant. 2010;45(6):1056-1061. doi:10.1038/bmt.2009.299

34. Locatelli F, Zecca M, Rondelli R, et al. Graft versus host disease prophylaxis with low-dose cyclosporine-A reduces the risk of relapse in children with acute leukemia given HLA-identical sibling bone marrow transplantation: Results of a randomized trial. Blood. 2000; 95(5):1572-1579.

35. Martin P, Bleyzac N, Souillet G, et al. Relationship between CsA trough blood concentration and severity of acute graft-versus-host disease after paediatric stem cell transplantation from matched-sibling or unrelated donors. Bone Marrow Transplant. 2003;32(8):777-784. doi:10.1038/sj.bmt.1704213
36. Duncan N, CraddockC. Optimizing the use of cyclosporin in allogeneic stem cell transplantation. Bone Marrow Transplant. 2006;38(3):169-174. doi:10.1038/sj.bmt.1705404

37. Ruutu T, Gratwohl A, de Witte T, et al. Prophylaxis and treatment of GVHD: EBMT-ELN working group recommendations for a standardized practice. Bone Marrow Transplant. 2014;49(2):168-173. doi:10. 1038/bmt.2013.107

38. Pulsipher MA, Chitphakdithai P, Logan BR, et al. Donor, recipient, and transplant characteristics as risk factors after unrelated donor PBSC transplantation: Beneficial effects of higher CD34+ cell dose. Blood. 2009;114(13):2606-2616. doi:10.1182/blood-2009-03-208355

39. Tsirigotis $P$, Shapira MY, Or R, et al. The number of infused CD34+ cells does not influence the incidence of GVHD or the outcome of allogeneic PBSC transplantation, using reduced-intensity conditioning and antithymocyte globulin. Bone Marrow Transplant. 2010;45(7):1189-1196. doi:10.1038/bmt.2009.331

40. Urbano-Ispizua A, Carreras E, Marín P, et al. Allogeneic transplantation of CD34+ selected cells from peripheral blood from human leukocyte antigen-identical siblings: Detrimental effect of a high number of donor CD34+ cells? Blood. 2001;98(8):2352-2357. 